\title{
Global changes in the diurnal cycle of surface ozone
}

\author{
Sarah A. Strode ${ }^{\mathrm{a}, \mathrm{b}, *}$, Jerald R. Ziemke ${ }^{\mathrm{b}, \mathrm{c}}$, Luke D. Oman ${ }^{\mathrm{b}}$, Lok N. Lamsal ${ }^{\mathrm{a}, \mathrm{b}}$, Mark A. Olsen ${ }^{\mathrm{b}, \mathrm{c}}$, \\ Junhua Liu ${ }^{\mathrm{a}, \mathrm{b}}$ \\ ${ }^{a}$ Universities Space Research Association, Columbia, MD, USA \\ ${ }^{\mathrm{b}}$ NASA Goddard Space Flight Center, Greenbelt, MD, USA \\ ${ }^{\mathrm{c}}$ Morgan State University, Baltimore, MD, USA
}

A R T I C L E IN F O

\section{Keywords:}

Ozone

Diurnal cycle

OMI

Trends

Global modeling

\begin{abstract}
A B S T R A C T
Changing emissions of $\mathrm{NO}_{\mathrm{x}}$ and other ozone precursors drive trends in both production and loss of surface ozone, leading to surface ozone trends that differ according to the time of day. Consequently, the magnitude of the diurnal cycle in surface ozone is changing in several regions of the world. Changes in the diurnal cycle of ozone have implications for the metrics used to assess the impact of ozone on human health and vegetation, since different metrics are sensitive to different portions of the diurnal cycle. We use a high resolution model simulation to examine global changes in the magnitude of the diurnal cycle of $\mathrm{O}_{3}$ between 1980 and 2015 . The simulation reproduces the negative trends in the tropospheric $\mathrm{NO}_{2}$ column over the eastern United States and Europe, and the positive trends over East Asia, seen by the Ozone Monitoring Instrument (OMI). It also gives a reasonable reproduction of the change in the diurnal cycle of surface ozone seen at rural sites in the eastern United States between the 1990s and 2000s. The simulation shows that the magnitude of the surface $\mathrm{O}_{3}$ diurnal cycle is increasing in regions with positive changes in $\mathrm{NO}_{\mathrm{x}}$ emissions, such as South and East Asia, and decreasing in regions with reductions in $\mathrm{NO}_{\mathrm{x}}$ emissions. It also shows changes in the diurnal cycle of the tropospheric ozone column, although these have fewer regions with statistically significant trends. These changes suggest that daily mean ozone is responding less than the mid-day ozone measured by the Total Ozone Mapping Spectrometer (TOMS) and OMI.
\end{abstract}

\section{Introduction}

Tropospheric ozone is a major concern for air quality in many parts of the world. Both short-term and long-term ozone exposure are associated with negative human health effects and mortality (USEPA, 2013; REVIHAAP, 2013; Turner et al., 2016). Exposure to ambient ozone concentrations is also linked to injury and reduced growth of vegetation (USEPA, 2013; Mills et al., 2018), and reduced crop yields (Avnery et al., 2011; Mauzerall and Wang, 2001; Van Dingenen et al., 2009).

Numerous different metrics are used to quantify ozone exposure for human and vegetation health. For example, Jerrett et al. (2009) used maximum daily $1-\mathrm{h}$ values in their calculation of ozone-related mortality risk, while Turner et al. (2016) used maximum daily 8-h concentrations and Carey et al. (2013) used annual averages. The calculation of mortality due to ozone exposure is sensitive to the choice of risk estimate (Malley et al., 2017). Several common exposure metrics for vegetation (M12, AOT40) are based on daylight hours and thus consider a 12-h period (Lefohn et al., 2017 and refs therein). Some metrics are also nonlinear. For example, the W126 metric often used for vegetation puts more weight on the hours with higher ozone concentrations. Surface ozone has a pronounced diurnal cycle, so the maximum 1-h concentration is often much larger than the average value for a 12-h period. Because different metrics are based on different portions of the ozone distribution, the magnitude and even sign of the ozone trend at a given location can change depending on the metric considered (Lefohn et al., 2017).

Pollution controls on $\mathrm{NO}_{\mathrm{x}}$ and VOC emissions have led to reductions in peak surface ozone over the eastern United States and parts of Europe. However, diurnal and seasonal differences in ozone chemistry lead to ozone trends that vary according to season, time of day, and percentile of the ozone distribution. While reductions in $\mathrm{NO}_{\mathrm{x}}$ typically reduce daytime summer ozone, reduced titration by $\mathrm{NO}_{\mathrm{x}}$ can increase nighttime and winter ozone. Cooper et al. (2012) report predominantly negative trends in 95th percentile ozone at rural U.S. stations for 1990-2010, shifting to more positive or insignificant trends at the 5th percentile. Simon et al. (2015) also found a compression of the U.S. ozone distribution due to decreases at the high end of the distribution and increases at the low end. This shift is also seen at European sites

\footnotetext{
* Corresponding author. NASA GSFC Code 614, Greenbelt, MD, 20771, USA.

E-mail address: sarah.a.strode@nasa.gov (S.A. Strode).
} 
(Koumoutsaris and Bey, 2012, and refs therein). In contrast, maximum daily 8-h (MDA8) ozone over Asia shows increasing trends (Lin et al., 2017 and refs therein). Furthermore, positive trends over East Asia for 2000-2014 are present for a wide range of surface ozone metrics (Chang et al., 2017). Surface observations show ozone further increased over China from 2013 to 2014 to 2016-2017 (Lu et al., 2018).

Changes in precursor emissions led to a shift in the seasonal cycle of ozone over the eastern U.S. between the 1990s and 2000s (e.g. Bloomer et al., 2010; Clifton et al., 2014; Strode et al., 2015). Eastern U.S. surface sites also show a shift in the diurnal cycle (Bloomer et al., 2010). Jhun et al. (2015) examined surface sites across the United States and found that warm season ozone decreased during midday only, while cold season ozone increased throughout the day. Yan et al. (2018) also found increasing trends in nighttime U.S. surface ozone across all seasons for 2004-2012 due to decreases in $\mathrm{NO}_{\mathrm{x}}$.

While surface observations provide valuable information on the diurnal cycle, multi-decadal observational records are not available in many regions of the world. Global atmospheric chemistry models can provide additional insights on changes in the diurnal cycle across the globe as well as the processes that drive them. Here, we use a global model to investigate changes in the diurnal cycle of ozone on a global scale, including regions where long-term surface observations are unavailable. Section 2 describes the methodology. Section 3 presents an evaluation of the model against observations and uses the model to investigate and attribute global changes in the diurnal cycle. We discuss implications for ozone trends and present conclusions in Section 4.

\section{Methods}

\subsection{MERRA2-GMI simulation}

We use the Modern-Era Retrospective analysis for Research and Applications (MERRA-2) GMI simulation (M2GMI; https://acd-ext.gsfc. nasa.gov/Projects/GEOSCCM/MERRA2GMI/) of the Goddard Earth Observing System (GEOS) Chemistry Climate Model (GEOSCCM). The GEOSCCM (Nielsen et al., 2017; Oman et al., 2013) uses the GEOS version 5 global atmospheric general circulation model (Molod et al., 2015) with the Global Modeling Initiative (GMI) chemistry mechanism (Duncan et al., 2007; Strahan et al., 2007) for trace gas chemistry and the Goddard Chemistry Aerosol Radiation and Transport (GOCART) module (Chin et al., 2002; Colarco et al., 2010) for aerosols. The GMI chemistry mechanism includes both stratospheric and tropospheric chemistry, with over 120 species and over 400 reactions. A chemical transport modeling study with GMI chemistry shows that it can reproduce many of the observed trends in surface ozone over the eastern and Midwestern United States (Strode et al., 2015).

The M2GMI simulation has 72 vertical levels and a horizontal resolution of c180 on the cubed sphere, which corresponds to approximately $50 \mathrm{~km}$. The output is on a $0.625^{\circ}$ longitude $\mathrm{x} 0.5^{\circ}$ latitude grid. M2GMI covers the period from 1980 to 2016. The simulation's meteorology is constrained by the MERRA- 2 reanalysis (Gelaro et al., 2017) temperature, pressure, and wind fields using a replay technique (Orbe et al., 2017).

M2GMI includes emissions of $\mathrm{CO}, \mathrm{NO}_{\mathrm{x}}$, and non-methane hydrocarbons. Methane is specified with an observationally constrained zonal-mean surface concentration. Fossil fuel and biofuel emissions come from the MACCity inventory (Granier et al., 2011) until 2010, and then follow the Representative Concentration Pathway 8.5 for more recent years. The MACCity emissions (http://accent.aero.jussieu.fr/ MACC_metadata.php) include sector-by-sector linear interpolation of the decadal Atmospheric Chemistry and Climate - Model Intercomparison Project (ACCMIP) emissions (Lamarque et al., 2010) to each year as well as seasonal scaling. Biomass burning emissions come from the Global Fire Emissions Dataset (GFED) version 4s (Giglio et al., 2013), which includes small fires (Randerson et al., 2012), for 1997-2016. The emissions switch from monthly to daily variability in
2003, when daily emissions become available (Mu et al., 2011). Prior to 1997, we use biomass burning emissions based on a GFED4s climatology with year-to-year variability imposed using regional scale factors derived from the Total Ozone Mapping Spectrometer (TOMS) aerosol index (Duncan et al., 2003). Biogenic emissions, including isoprene, are calculated within GMI using the Model of Emissions of Gases and Aerosols from Nature (MEGAN) model (Guenther et al., 1999, 2000) and vary in space and time as a function of the meteorology. In particular, there is a significant positive trend in the calculated global total isoprene and monoterpene emissions over the simulation. Lightning $\mathrm{NO}_{\mathrm{x}}$ emissions have monthly variability based on the MERRA-2 detrended cumulative mass flux (Allen et al., 2010), with seasonal constraints from the Lightning Imaging Sensor (LIS)/Optical Transient Detector (OTD) v2.3 climatology (Cecil et al., 2014).

The M2GMI simulation includes hourly output for ozone at each model level including the surface and tropospheric column ozone. The tropospheric ozone column is derived using a blended definition of the tropopause based on the temperature lapse rate in the tropics and potential vorticity in the extratropics. The chemical tendency of ozone, which includes chemical production, chemical loss, and deposition terms, is output on constant pressure levels every $3 \mathrm{~h}$.

\subsection{Observations}

We use observations of the tropospheric $\mathrm{NO}_{2}$ column from the Aura Ozone Monitoring Instrument (OMI) (Levelt et al., 2006) to evaluate the simulated trends in $\mathrm{NO}_{\mathrm{x}}$ concentrations. OMI tropospheric $\mathrm{NO}_{2}$ columns are available beginning in October 2004, but we use the data from 2005 onwards. We use the daily version 3 product (Krotkov et al., 2017), gridded to the same resolution as the model simulation. We sample the model at the OMI overpass time, which is $\sim 13: 30$ local time, for comparison. We calculate the trend in the OMI and model $\mathrm{NO}_{2}$ following the method of Ziemke et al. (submitted). In particular, we use multiple regression to fit the seasonal cycle with a series of sines and cosines along with the linear trend for each month. Seasonal trends are calculated as the average of the relevant monthly trends. We consider trends to be statistically significant if they exceed the two standard deviation uncertainties on the trend.

The Tropospheric Ozone Assessment Report (TOAR) provides gridded surface ozone metrics that incorporate data from North America, Europe, Asia, and other regions (Schultz et al., 2017). We use the $2 \times 2$ degree gridded products for daytime ( $8 \mathrm{am}-8 \mathrm{pm})$ and nighttime $(8 \mathrm{pm}-8 \mathrm{am})$ average rural ozone concentrations to evaluate the simulation's representation of day versus nighttime ozone differences in different decades globally. The TOAR gridded observations are provided as semi-decadal averages.

We also use observations from the U.S. Environmental Protection Agency (EPA) Clean Air Status and Trends Network (CASTNET) network of rural surface observations to evaluate the simulated diurnal cycle over the northeastern United States. For this analysis, we select 9 stations in the region from $35^{\circ}$ to $40^{\circ} \mathrm{N}, 80^{\circ}-70^{\circ} \mathrm{W}$ that have at least 21 years of data. These sites are ARE128, BEL116, CTH110, KEF112, LRL117, PAR107, PED108, PSU106, and WSP144. We exclude SHN418 due to its high elevation. Table 1 describes these sites.

\section{Results}

\subsection{Model evaluation}

We evaluate how well the MERRA-2 GMI simulation reproduces the observed distribution, diurnal variability, and decadal changes of surface ozone. Since changes in $\mathrm{NO}_{\mathrm{x}}$ are a major driver of ozone changes, we also examine the simulated trends in $\mathrm{NO}_{2}$.

Fig. 1 shows the seasonal trends in tropospheric column $\mathrm{NO}_{2}$ from OMI for 2005-2015. Fig. 2 shows the corresponding trends in the M2GMI simulation. There is broad agreement in the spatial distribution 
Table 1

Site information for the CASTNET observations used in this study.

\begin{tabular}{llcccc}
\hline Site ID & Site Name & State & Latitude & Longitude & Elevation (m) \\
\hline ARE128 & Arendtsville & PA & 39.9 & -77.3 & 266 \\
BEL116 & Beltsville & MD & 39.0 & -76.8 & 47 \\
CTH110 & Connecticut Hill & NY & 42.4 & -76.7 & 511 \\
KEF112 & Kane Experimental & PA & 41.6 & -78.8 & 618 \\
& Forest & & & & \\
LRL117 & Laurel Hill State Park & PA & 40.0 & -79.3 & 609 \\
PAR107 & Parsons & WV & 39.1 & -79.7 & 510 \\
PED108 & Prince Edward & VA & 37.2 & -78.3 & 149 \\
PSU106 & Penn State & PA & 40.7 & -77.9 & 364 \\
WSP144 & Washington's Crossing & NJ & 40.3 & -74.9 & 59 \\
& & & & & \\
\hline
\end{tabular}

of $\mathrm{NO}_{2}$ trends between the model and OMI, with negative trends over the eastern U.S. and parts of western Europe, and positive trends over East Asia and to a lesser extent South Asia. The negative trends over the eastern U.S. are most pronounced over the Northeast. Both the model and observations show stronger trends in December-Feb. than June-August. The simulated trends are statistically significant over larger regions than the OMI trends, likely due to the lack of noise in the model. However, the broad region of positive trend over East Asia seen in the simulation is also visible in the OMI trends if we do not consider the statistical significance. The magnitude of the positive trend over China is overestimated in the simulation compared to OMI. This is consistent with the use of the MACCity and RCP8.5 emission scenario, which does not account for the downturn in Chinese $\mathrm{NO}_{\mathrm{x}}$ emissions since 2011 (Krotkov et al., 2016; Liu et al., 2016). Since both the simulation and the observations show strong trends over eastern China and the northeastern United States, we focus much of our analysis on these two regions.

We examine how well the simulation reproduces the global distribution of daytime and nighttime surface ozone compared to the gridded rural observations from the TOAR for the period from 2005 to 2009 (Fig. 3). The spatial correlation between the simulated and observed ozone is higher for daytime ozone ( $r=0.71$ and $r=0.82$ for Dec.-Feb. and June-Aug., respectively) than for nighttime ozone $(\mathrm{r}=0.60$ and $\mathrm{r}=0.49$ for Dec.-Feb. and June-Aug., respectively). While the simulation is biased high compared to the observations in both day and night, the bias is larger for nighttime. This is particularly true for June-Aug., when the simulation is high biased by $49 \%$ in the night but only $17 \%$ in the day. The higher bias at night compared to day suggests that the model generally underestimates the magnitude of the diurnal cycle of ozone, since higher ozone values typically occur during the day.

We next evaluate how well the simulation captures the temporal changes in daytime and nighttime surface ozone seen in the TOAR rural observations (Fig. 4). Since the TOAR gridded observations are provided as semi-decadal averages, we compare averages for the following periods: 1995-1999, 2005-2009, and 2010-2014. We exclude the 2000-2004 average since eastern U.S. ozone concentrations decreased especially rapidly over this period (EPA, 2011), and instead we focus on the years prior to and after this change. Between 1995-1999 and 2005-2009, both the simulation and observations show that in both daytime and nighttime wintertime ozone increased over N. America, changed little over Europe, and decreased over Asia, although the simulation underestimates the magnitude of the Asian decrease (Fig. 4a). In summertime, both model and observations show a decrease over $\mathrm{N}$. America and Europe and an increase over Asia (Fig. 4b). The magnitude of the observed changes over both N. America and Asia is larger for daytime than nighttime. The simulation captures this difference for $\mathrm{N}$. America but not for Asia. The observations for 2010-2014 versus 2005-2009 (Fig. 4c and d) show that wintertime ozone increased over N. America and Europe and slightly decreased over Asia, while summertime ozone decreased in all three regions. The simulation captures the sign of these changes for all cases except Asian winter. It also agrees with the observed change in daytime ozone being larger than for nighttime ozone in summer over N. America and Europe. We note that the Asia region includes observations over South Korea for the 2010-2014 vs. 2005-2009 comparison, but not for the 2005-2009 vs.
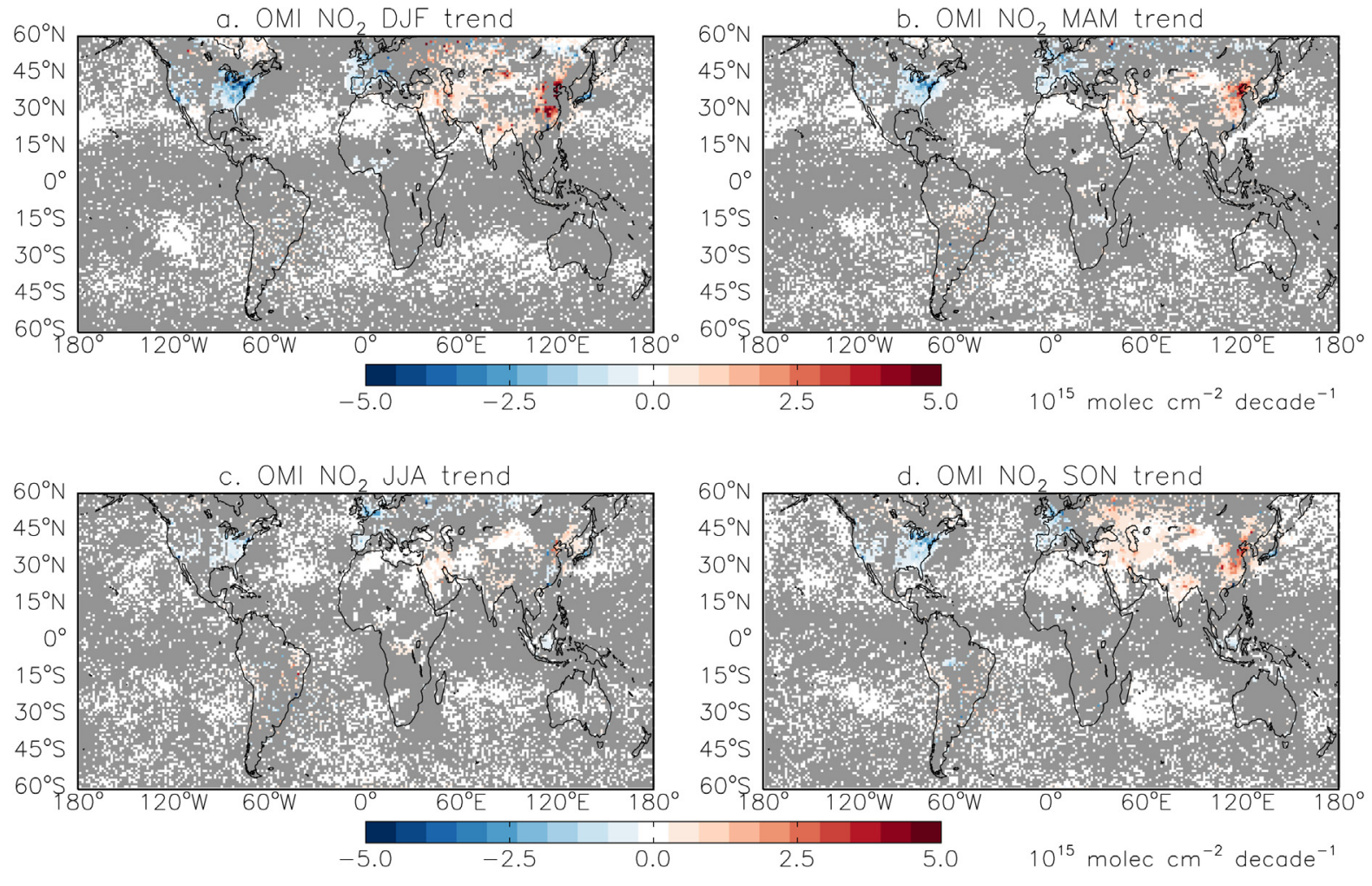

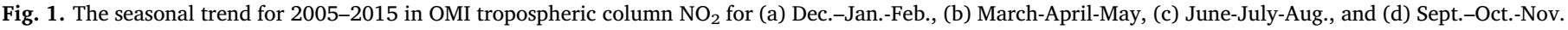
Regions where the trend is not statistically significant are shaded gray. 

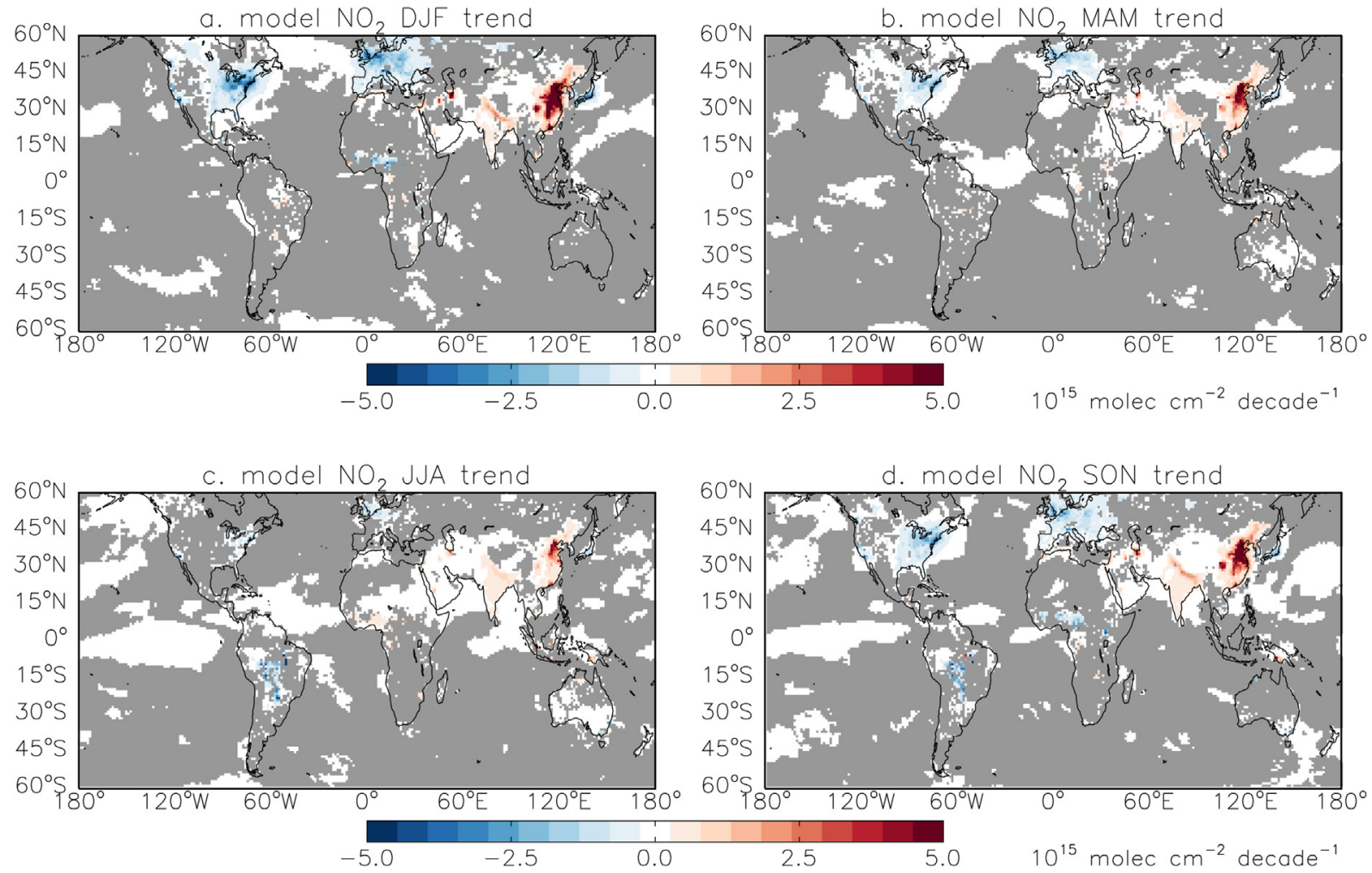

Fig. 2. The seasonal trend for 2005-2015 in MERRA-2 GMI tropospheric column $\mathrm{NO}_{2}$ for (a) Dec.-Jan.-Feb., (b) March-April-May, (c) June-July-Aug., and (d) Sept.-Oct.-Nov. Regions where the trend is not statistically significant are shaded gray.
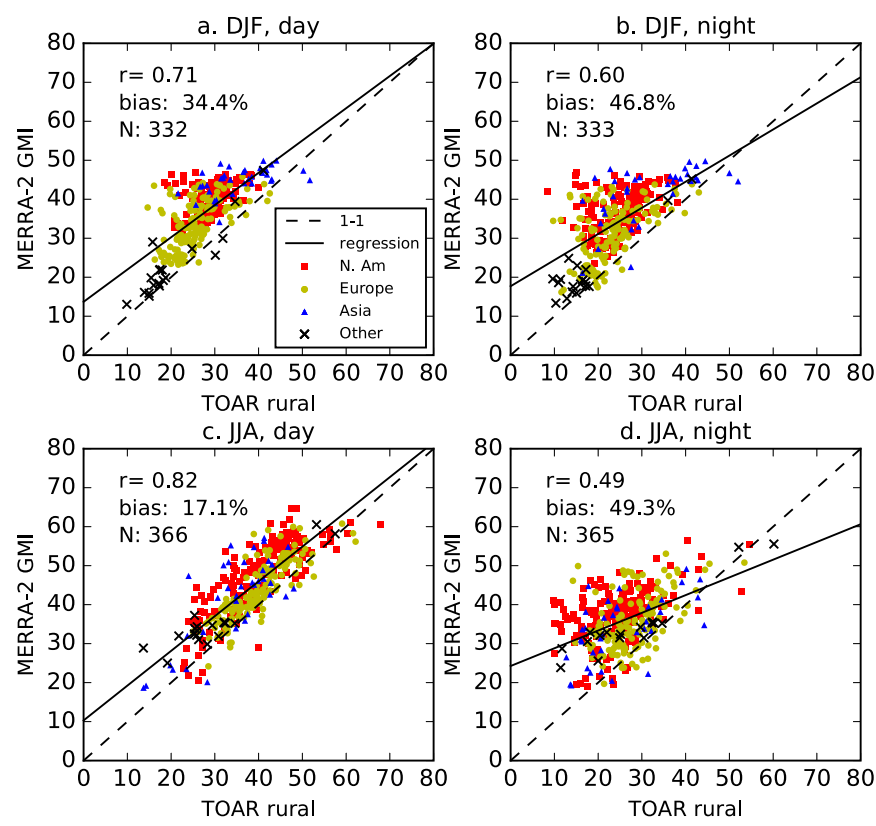

Fig. 3. Surface ozone concentrations (in ppb) averaged over 2005-2009 for the MERRA-2 GMI simulation versus the TOAR rural gridded observations for (a) Dec.-Feb. daytime, (b) Dec.-Feb. nighttime, (c) June-Aug. daytime, and (d) June-Aug. nighttime. Observations from Asia are in blue, Europe in yellow, N. America in red, and other regions in black. The best-fit line from linear regression (solid) and the 1-1 line (dashed) are also shown, along with the spatial correlation coefficient ( $r$ ), mean bias, and number of samples $(\mathrm{N})$. (For interpretation of the references to colour in this figure legend, the reader is referred to the Web version of this article.)
1995-1999 comparison as TOAR observations for South Korea are not available for the 1990s. Excluding the Korean observations for the 2010-2014 vs. 2005-2009 comparison would result in a positive change in both daytime and nighttime DJF observed ozone, but the simulation would still overestimate the positive change. Overall, the better agreement between the simulated and observed changes over $\mathrm{N}$. America and Europe compared to Asia provides greater confidence in the simulated changes in the diurnal cycle for N. America and Europe.

We further compare the diurnal cycle over the northeastern U.S. with observations, since this region is a particular focus of our analysis. Fig. 5 shows the diurnal cycle of ozone for the 1990s and 2000s from CASTNET observations compared to the MERRA-2 GMI simulation sampled at the CASTNET locations. The diurnal cycle is generally well captured by the model for both decades, with the exception of a high bias in July ozone that is most pronounced in the daytime. A smaller high bias in afternoon ozone is also present in October, while the simulation is biased low throughout the day and night in January. In general, the model overestimates the magnitude of the diurnal cycle except in Summer. However, there is good agreement between the simulation and the observations on the timing of the peaks and minima of the diurnal cycle, and the simulation captures the observed decreases in ozone between the 1990s and 2000s. The observations show a decrease in the magnitude of the cycle, calculated as the maximum minus the minimum, from 9.0 to $8.3 \mathrm{ppb}$ between the 1990s and 2000s in January, while the model shows a decrease from 12 to $10 \mathrm{ppb}$. The observations in April show a decrease from $22 \mathrm{ppb}$ to $20 \mathrm{ppb}$, while the model shows a decrease from $26 \mathrm{ppb}$ to $21 \mathrm{ppb}$. The observations in July show a decrease from $39 \mathrm{ppb}$ to $32 \mathrm{ppb}$, while the model shows a decrease from $37 \mathrm{ppb}$ to $31 \mathrm{ppb}$. The observations in October show a decrease from $24 \mathrm{ppb}$ to $20 \mathrm{ppb}$, while the model shows a decrease from $27 \mathrm{ppb}$ to $23 \mathrm{ppb}$. Our July results are consistent with the results of (Schnell et al., 2015), who found that the models participating in the multi-model ACCMIP study (Lamarque et al., 2013) overestimated surface ozone over eastern North America in June-August but 

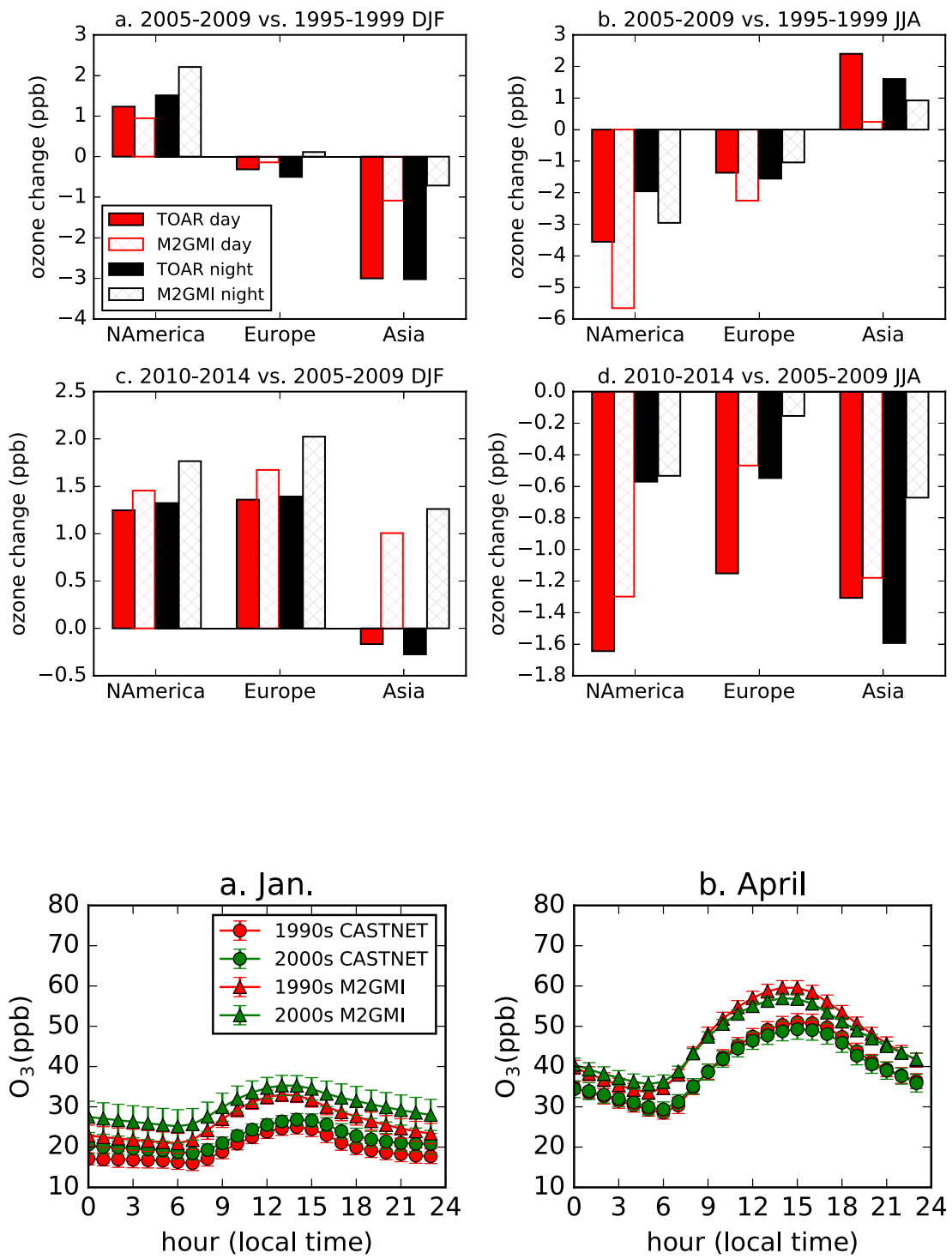

Fig. 5. The diurnal cycle of surface ozone over the northeast U.S. for CASTNET observations (circles) and the M2GMI simulation sampled at the CASTNET locations (triangles) averaged over the 1990s (red) and 2000s (green) for a) January, b) April, c) July, and d) October. Error bars represent the standard deviation in time of the regional average. The peak to peak magnitude for each of the four months is shown for e) the CASTNET sites and f) the M2GMI simulation. The following CASTNET sites are included: ARE128, BEL116, CTH110, KEF112, LRL117, PAR107, PED108, PSU106, and WSP144. (For interpretation of the references to colour in this figure legend, the reader is referred to the Web version of this article.)
Fig. 4. The change in surface ozone for the (a,b) 2005-2009 2010-2014 average compared to the 2005-2009 average for (a,c) Dec.-Feb. and (b,d) June-Aug. over N. America, Europe, bars show the M2GMI simulation. Daytime changes are in red while nighttime changes are in black. (For interpretation of the references to colour in this figure legend, the reader is referred to the Web version of this article.)

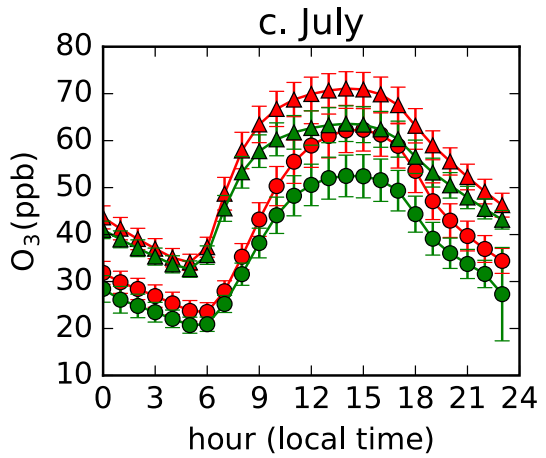

e. CASTNET Magnitude

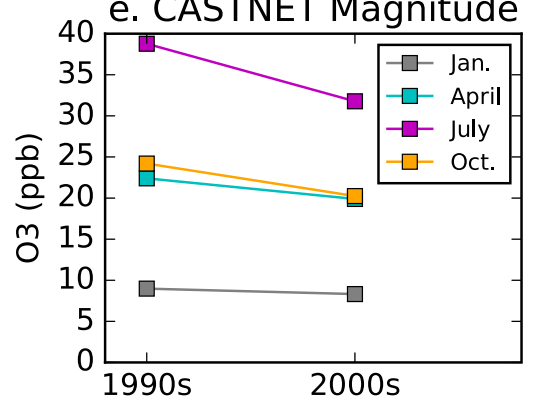

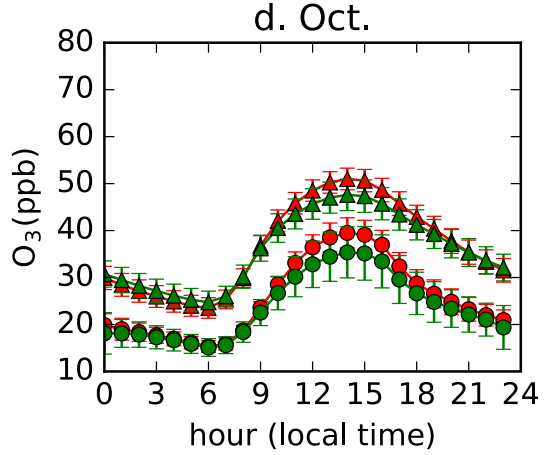

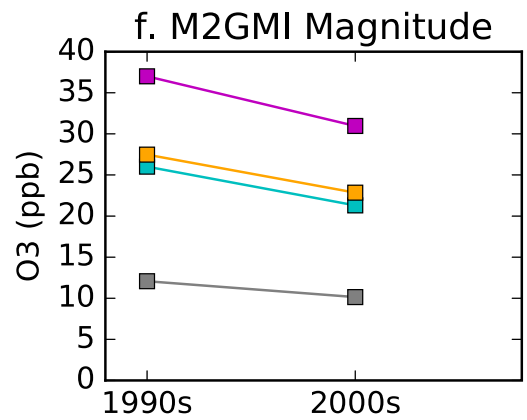




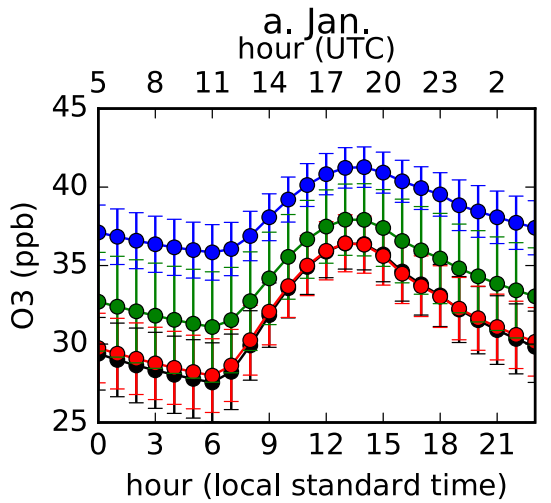

hour July

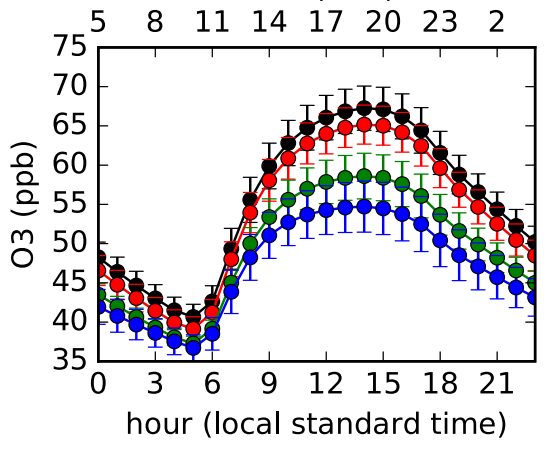

e. Diurnal Magnitude

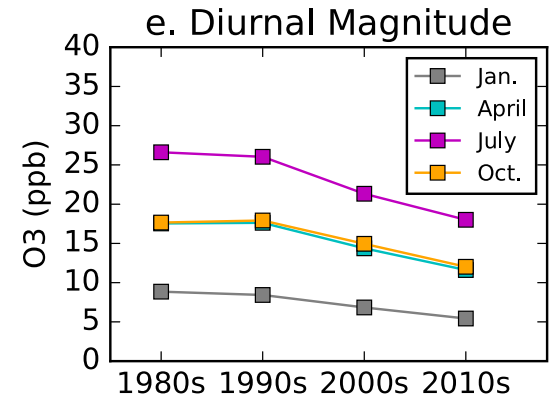

b. April

hour (UTC)

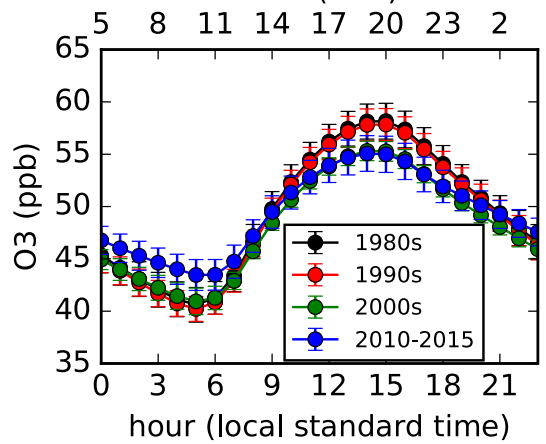

d. Oct.

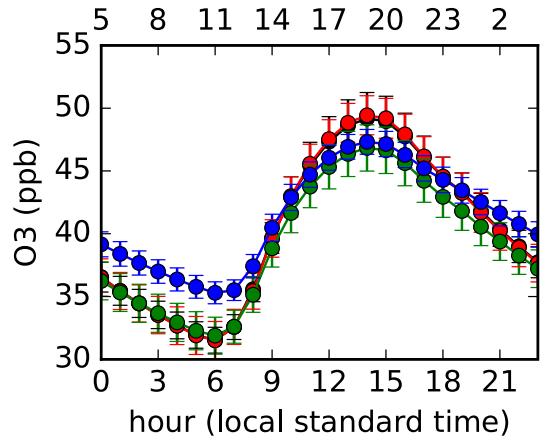

Fig. 6. The diurnal cycle of surface ozone over the eastern United States for (a) January, (b) April, (c) July, and (d) October, as well as (e) the peak to peak magnitude of the diurnal cycle by decade. We define the eastern U.S. as $80^{\circ} \mathrm{W}$ $70^{\circ} \mathrm{W}, 35^{\circ} \mathrm{N}-45^{\circ} \mathrm{N}$. The lower $\mathrm{x}$-axis in a-d gives time in local standard time, while the upper axis give time in UTC. Circles represent the multi-year average for the 1980s (black), 1990s (red), 2000s (green), and 2010-2015 (blue). Error bars represent the standard deviation for the corresponding time periods. (For interpretation of the references to colour in this figure legend, the reader is referred to the Web version of this article.) underestimated the peak-to-peak amplitude of the diurnal cycle. Overall, this analysis gives us confidence that the model does a reasonable job of capturing observed changes in the diurnal cycle for this region.

\subsection{Regional shifts in the diurnal cycle}

We use the model to examine changes in the diurnal cycle over the northeastern U.S. and eastern China over four decades. This modelbased analysis extends the temporal and spatial range of our investigation beyond what is available from observations.

Fig. 6 shows the simulated regional average diurnal cycle for one month in each season for the 1980s through 2015. While this analysis includes model output for every grid box in the region, not just the CASTNET locations, the overall features for the 1990s and 2000s are consistent with the picture shown in Fig. 5. The compression of the diurnal cycle between the 1990s and 2000s becomes even more apparent for 2010-2015. In particular, the afternoon ozone peak in July decreases in the 2010-2015 period while the nighttime minima in April and October increases. The simulation shows little change between the 1980 s and 1990s.

We next use the simulation to examine the diurnal cycle over eastern China, where long-term data are not readily available. We note that our results for this region have a higher uncertainty than the results for the eastern U.S. given the weaker model performance over China shown in Fig. 4. The diurnal cycle changes over eastern China are largely opposite to those over the eastern U.S., showing an increase in the magnitude of the diurnal surface ozone cycle in all seasons (Fig. 7). This is consistent with the positive trend in $\mathrm{NO}_{2}$, which we expect to drive higher ozone production in the day and more ozone titration at night. In January, there are significant decreases in the ozone minimum, particularly between the 1990s and 2000s and the 2000s and 2010s, compared to smaller changes in the maximum. In July, there are significant increases in the maximum surface ozone between the 1990s and later years, and only small changes in the minimum. April and October both show an in increase in the maximum and decrease in the minimum for 2010-2015 compared to the 1980s.

Figs. 8 and 9 show the diurnal cycle of the net chemical tendency of ozone (production minus loss) for the eastern U.S. and eastern China, respectively. We use the tendency from 3-hourly pressure-level output from the simulation. We select the pressure level second-closest to the surface since the level closest to the surface includes the effects of dry deposition, which makes the overall tendencies more negative. Figs. 8 and 9 both show that the strongest positive ozone tendency occurs in the local morning for all decades and seasons, with the peak tendency occurring several hours before the peak ozone, as expected. Both 

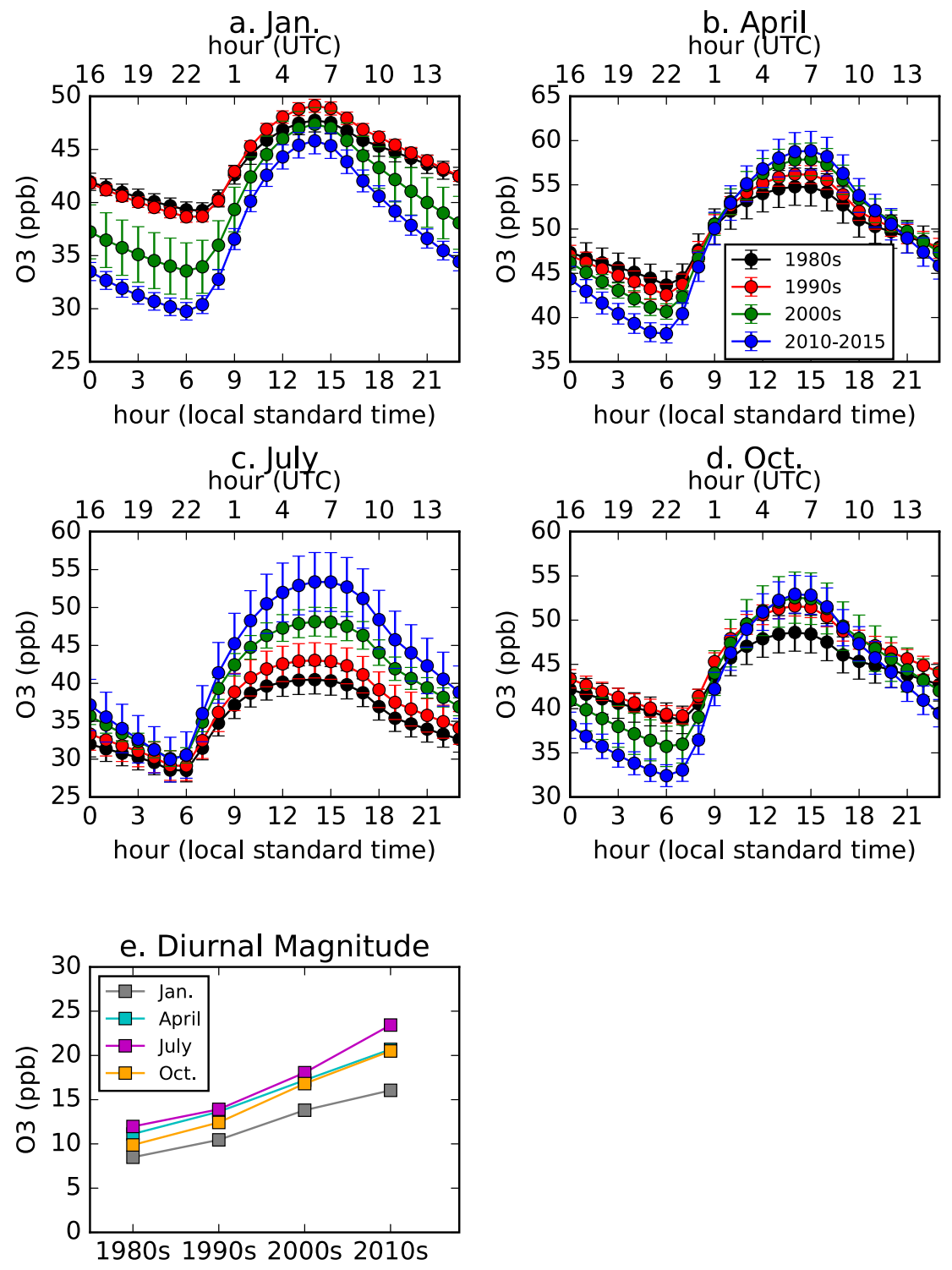

Fig. 7. As in Fig. 6, but for eastern China $\left(110^{\circ} \mathrm{E}-125^{\circ} \mathrm{E}, 20^{\circ} \mathrm{N}-45^{\circ} \mathrm{N}\right)$.

regions also show net ozone loss at night. The diurnal cycle of the chemical tendency, like the diurnal cycle of surface ozone itself, shows compression over time over the eastern U.S., with lower levels of both peak production and peak loss in more recent decades. There is also a shift in the timing of the peak net production in July, with 2010-2015 showing a peak at 7 a.m. while the 1980s and 1990s have a broader maximum between 7am and 10am. The opposite shift occurs in January. In contrast, the simulation shows an increase in the amplitude of the diurnal cycle of chemical tendency over eastern China, with both production and loss increasing in recent decades.

\subsection{Global changes in the diurnal cycle}

We next extend our analysis to cover the entire globe. We use the MERRA-2 GMI simulation to calculate the change in the surface ozone diurnal cycle between the 1980 s and the 2006-2015 period. Fig. 10 shows the difference in the peak-to-peak magnitude of the diurnal cycle between the two periods for each surface grid box. We use the interannual variability in the magnitude to calculate the standard deviation for each period and determine the statistical significance of the change using a $t$-test for the difference of means (von Storch and Zwiers, 1999). The changes in magnitude closely follow changes in $\mathrm{NO}_{\mathrm{x}}$ emissions, with the magnitude increasing in regions where $\mathrm{NO}_{\mathrm{x}}$ emissions increased and decreasing in regions where $\mathrm{NO}_{\mathrm{x}}$ decreased. As expected from the previous section, we find significant negative changes in the surface ozone diurnal cycle magnitude over the eastern United States and Europe, and significant positive changes over east Asia and India. Both positive and negative significant changes are present in other regions as well. In particular, the simulation predicts an increase in the magnitude over equatorial Africa in January and July due to increases in biomass burning, and in South Africa in all seasons due to increases in fossil fuel $\mathrm{NO}_{\mathrm{x}}$ emissions.

Recent studies have used observations from OMI and the Microwave Limb Sounder (MLS) onboard the Aura satellite to quantify changes in the tropospheric ozone column (David and Nair, 2013; Gaudel et al., 2018; Zhang et al., 2016; Ziemke et al., submitted). Since the Aura overpass time occurs in the early afternoon, close to the daily peak in surface ozone, we next consider whether there is a significant change in the diurnal cycle of the tropospheric ozone column between the 1980s and the 2006-2015 period. While OMI/MLS data is not available prior to 2004, ozone data from the TOMS instrument is available back to the 1980s (https://disc.gsfc.nasa.gov). TOMS ascending node crosses the equator at noon. Our simulation suggests that the global mean peak-topeak magnitude of the diurnal cycle in the tropospheric ozone column 

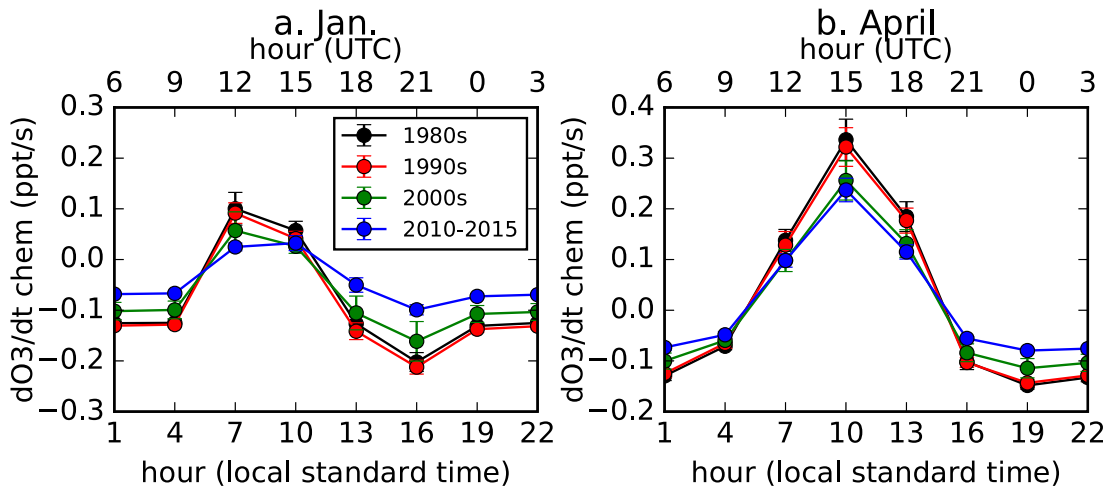

c. July
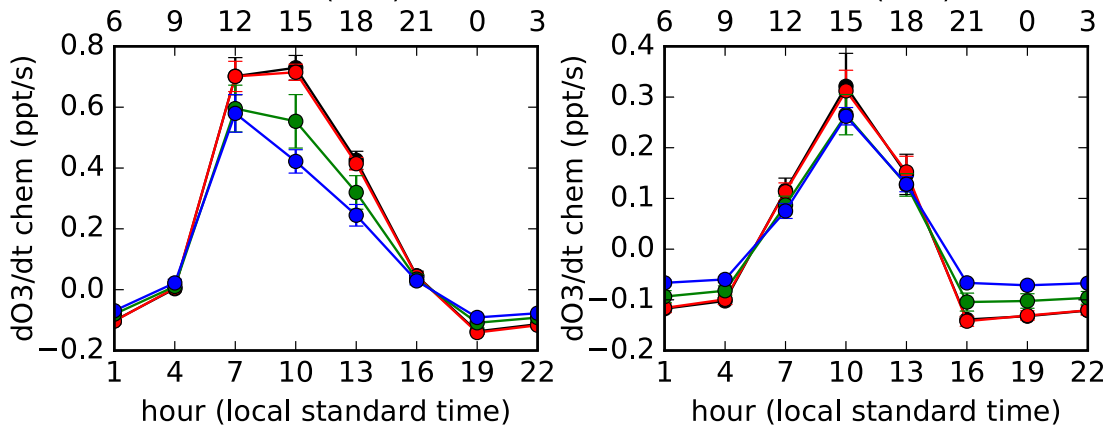

Fig. 8. The diurnal cycle of the chemical tendency of ozone $\left(\mathrm{dO}_{3} / \mathrm{dt}\right.$ due to production and loss processes) over the eastern United States for (a) January, (b) April, (c) July, and (d) October, as well as (e) the peak to peak magnitude of the tendency. We use the tendency output for one pressure level above the surface. We define the eastern U.S. as $80^{\circ} \mathrm{W}-70^{\circ} \mathrm{W}$, $35^{\circ} \mathrm{N}-45^{\circ} \mathrm{N}$. The lower $\mathrm{x}$-axis in a-d gives time in local standard time, while the upper axis give time in UTC. Circles represent the multi-year average for the 1980s (black), 1990s (red), 2000s (green), and 2010-2015 (blue). Error bars represent the standard deviation for the corresponding time periods. (For interpretation of the references to colour in this figure legend, the reader is referred to the Web version of this article.)

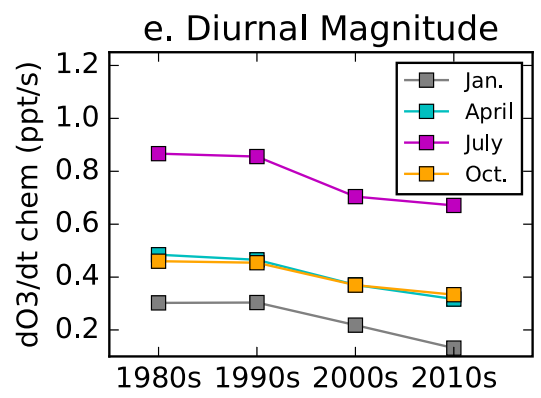

is approximately $1 \mathrm{DU}$, but values above $9 \mathrm{DU}$ are present for some locations.

Fig. 11 shows the change in the simulated diurnal cycle of the tropospheric ozone column. The patterns of positive and negative change are similar to that of the surface ozone (Fig. 10), but fewer grid boxes have a statistically significant change in the column. A few regions with statistically significant changes in the column do emerge however. An increase in the diurnal cycle is evident over parts of India in all four months, and over eastern China in July and October. A decrease in the diurnal cycle is evident over the eastern U.S. in July. The average change over eastern China in July is $0.5 \mathrm{DU}$, with changes in individual grid boxes reaching 2 DU. For comparison, Ziemke et al. (submitted) find trends in the OMI/MLS tropospheric ozone column of approximately 2 DU decade ${ }^{-1}$ over eastern China. Within the MERRA2-GMI simulation, we find that the 2005-2015 tropospheric ozone column trend over eastern China is 3-5\% larger, depending on the season, when we sample the model at the OMI overpass time compared to using the daily mean. This suggests that trends inferred from satellites with midday overpasses are most indicative of the trends in peak ozone and may overestimate or underestimate the trend in the daily mean in regions where emissions are changing. We note that the diurnal cycle is largest near the surface, where instruments such as OMI have lower sensitivity. Petetin et al. (2016) found that aircraft observations of ozone above Frankfurt show no discernible diurnal cycle above $750 \mathrm{hPa}$. Our estimate of the effect of the changing diurnal cycle on observed trends in the tropospheric column is thus likely to be an upper bound.

\section{Discussion and conclusions}

We use a high resolution $(50 \mathrm{~km})$ global model simulation constrained by reanalysis meteorology to investigate changes in the diurnal cycle of surface ozone between 1980 and 2015. The simulated trends in the tropospheric $\mathrm{NO}_{2}$ column show good agreement with observations from OMI, suggesting that temporal changes in the simulation's $\mathrm{NO}_{\mathrm{x}}$ emissions for the last decade are reasonable. We evaluate the simulated ozone against surface observations from the TOAR database. Although the simulated ozone is biased high compared to the observations, particularly at night, the simulation is able to capture many of the observed decadal scale changes in surface ozone. The agreement between simulated and observed ozone is best during daytime in the summer, suggesting that further research is needed into the causes of winter and nighttime biases. For example, Lin et al. (2008) found the representation of the planetary boundary layer to be a key factor in accurately simulating the diurnal cycle of surface ozone over the United States. We find that the simulated reduction in the magnitude of the diurnal cycle over the eastern United States agrees well with observations from the CASTNET network.

We examined changes in the magnitude of the simulated diurnal 

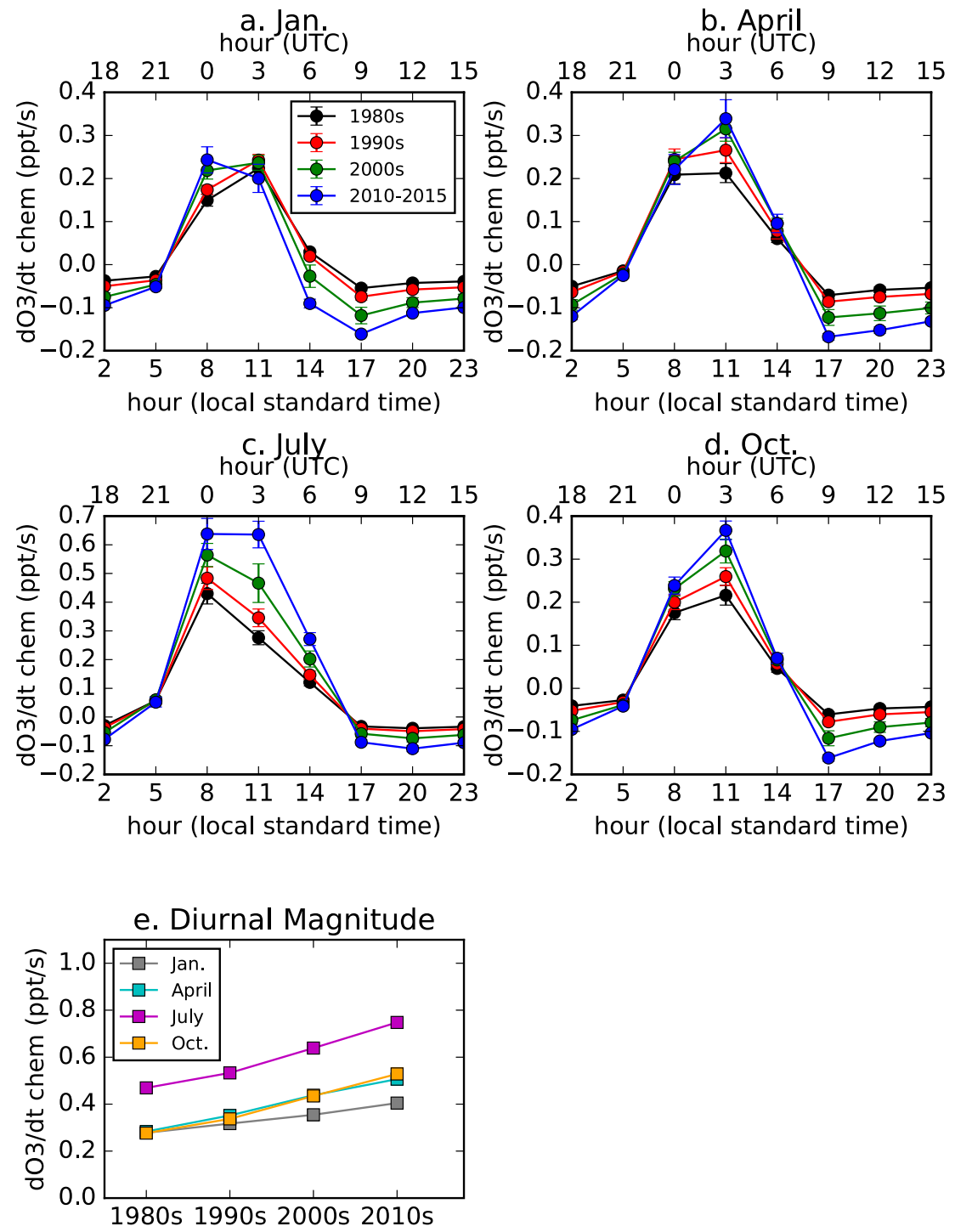

Fig. 9. As in Fig. 8, but for eastern China $\left(110^{\circ} \mathrm{E}-125^{\circ} \mathrm{E}, 20^{\circ} \mathrm{N}-45^{\circ} \mathrm{N}\right)$.
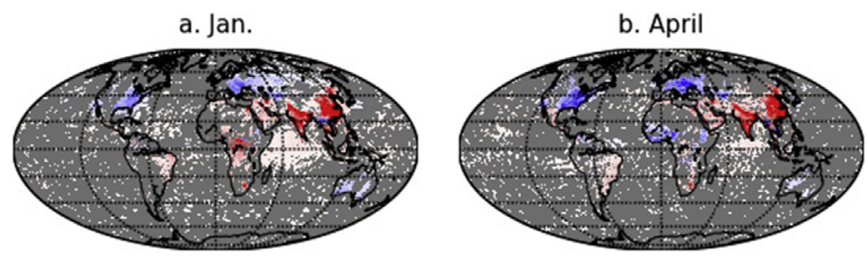

c. July
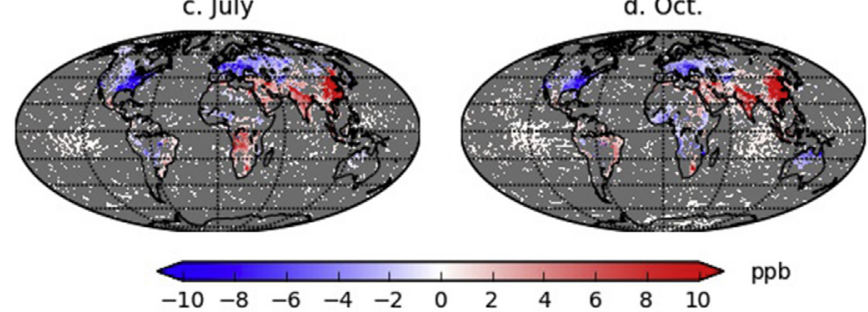

Fig. 10. The change in the peak-to-peak magnitude of the simulated surface ozone diurnal cycle in a) January, b) April, c) July, and d) October. The difference is calculated as the mean of 2006-2015 minus the mean of 1980-1989. Areas where the change is not statistically significant are grayed out.
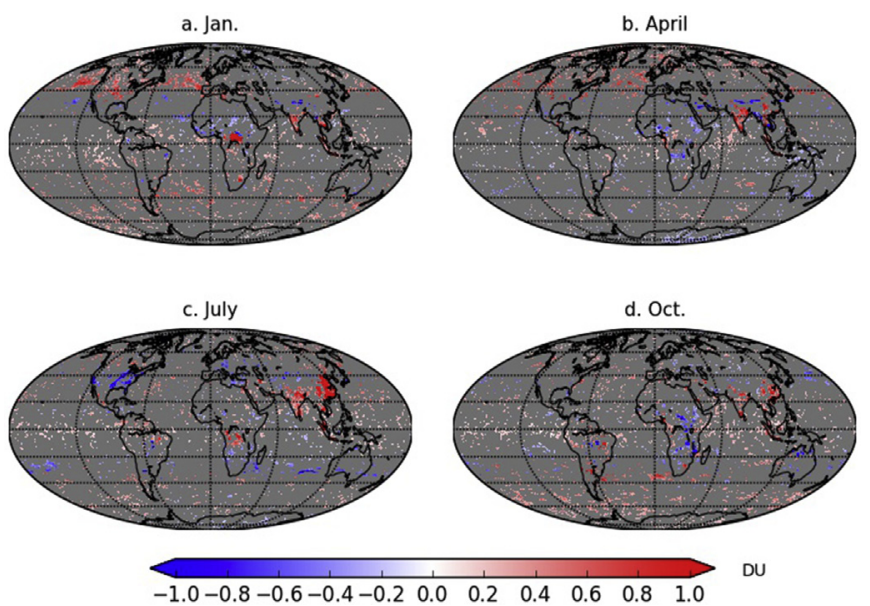

Fig. 11. The change in the peak-to-peak magnitude of the simulated tropospheric ozone column diurnal cycle in a) January, b) April, c) July, and d) October. The difference is calculated as the mean of 2006-2015 minus the mean of 1980-1989. Areas where the change is not statistically significant are grayed out. 
cycle of surface ozone between the 1980s and 2015 for all regions of the globe, since many locations lack long-term surface observations. Regions with increasing $\mathrm{NO}_{\mathrm{x}}$ emissions, such as East Asia, South Asia, and parts of Africa, show increases in the magnitude of the diurnal cycle. Regions with decreasing $\mathrm{NO}_{\mathrm{x}}$ emissions, such as the eastern United States and Europe, show compression of the diurnal cycle. Examination of the model's chemical tendency diagnostic shows that increases in the magnitude of the diurnal cycle over East Asia are due to both an increase in daytime production and an increase in nighttime loss. The reduced magnitude over the eastern U.S. is due to both a reduction in daytime production and a reduction in nighttime loss, consistent with the dual role of $\mathrm{NO}_{\mathrm{x}}$ in driving ozone photochemistry in the day and ozone titration at night.

Decadal shifts in the diurnal cycle of ozone have important implications for the trends in different ozone metrics. Fleming et al. (2018) show notable differences as well as broad similarities in the observed trends in 5 different health-related ozone metrics. Since the magnitude of the diurnal cycle increases in response to rising $\mathrm{NO}_{\mathrm{x}}$ emissions and decreases in response to declining $\mathrm{NO}_{\mathrm{x}}$ emissions, metrics that focus on peak daytime concentrations, such as the maximum daily 1-h average or maximum daily 8-h average, will show stronger trends in response to changes in $\mathrm{NO}_{\mathrm{x}}$ emissions than the daily mean. This effect is present in the tropospheric column as well as the surface ozone, although there are fewer regions with statistical significance. Consequently, changes in the diurnal cycle affect the interpretation of tropospheric ozone trends from instruments such as TOMS and OMI/MLS, since they observe ozone close to its daily maximum.

In the future, more ozone measurements would be valuable to confirm the simulated global changes in the diurnal cycle of ozone. Observations from geostationary satellites, such as TEMPO and GEMS, will also provide valuable constraints on the diurnal cycle of tropospheric ozone.

\section{Acknowledgements}

We wish to acknowledge the NASA Atmospheric Composition Modeling and Analysis Program (Grant NNX17AG58G) and the NASA Modeling, Analysis, and Prediction program for funding this work. Computer resources for the MERRA-2 GMI simulation were provided by the NASA Center for Climate Simulation.

\section{Appendix A. Supplementary data}

Supplementary data to this article can be found online at https:// doi.org/10.1016/j.atmosenv.2018.11.028.

\section{References}

Allen, D., Pickering, K., Duncan, B., Damon, M., 2010. Impact of lightning NO emissions on North American photochemistry as determined using the Global Modeling Initiative (GMI) model. J. Geophysic. Res. Atmos. 115. https://doi.org/10.1029/ 2010jd014062.

Avnery, S., Mauzerall, D., Liu, J., Horowitz, L., 2011. Global crop yield reductions due to surface ozone exposure: 1 . Year 2000 crop production losses and economic damage. Atmos. Environ. 45 (13), 2284-2296. https://doi.org/10.1016/j.atmosenv.2010.11. 045 .

Bloomer, B.J., Vinnikov, K.Y., Dickerson, R.R., 2010. Changes in seasonal and diurnal cycles of ozone and temperature in the eastern US. Atmos. Environ. 44 (21-22), 2543-2551. https://doi.org/10.1016/j.atmosenv.2010.04.031.

Carey, I.M., Atkinson, R.W., Kent, A.J., Staa, Tv, Cook, D.G., et al., 2013. Mortality associations with long-term exposure to outdoor. Air Pollution in a National English Cohort 187 (11), 1226-1233. https://doi.org/10.1164/rccm.201210-17580C.

Cecil, D., Buechler, D., Blakeslee, R., 2014. Gridded lightning climatology from TRMM LIS and OTD: Dataset description. Atmos. Res. 135, 404-414. https://doi.org/10. 1016/j.atmosres.2012.06.028.

Chang, K., Petropavlovskikh, I., Cooper, O., Schultz, M., Wang, T., 2017. Regional trend analysis of surface ozone observations from monitoring networks in eastern North America, Europe and East Asia. Elementa-Science of the Anthropocene 5. https://doi. org/10.1525/elementa.243.

Chin, M., Ginoux, P., Kinne, S., Torres, O., Holben, B., et al., 2002. Tropospheric aerosol optical thickness from the GOCART model and comparisons with satellite and Sun photometer measurements. J. Atmos. Sci. 59 (3), 461-483. https://doi.org/10.1175/ 1520-0469(2002)059<0461:TAOTFT > 2.0.CO;2.

Clifton, O.E., Fiore, A.M., Correa, G., Horowitz, L.W., Naik, V., 2014. Twenty-first century reversal of the surface ozone seasonal cycle over the northeastern United States. Geophys. Res. Lett. 41 (20), 7343-7350. https://doi.org/10.1002/2014g1061378.

Colarco, P., da Silva, A., Chin, M., Diehl, T., 2010. Online simulations of global aerosol distributions in the NASA GEOS-4 model and comparisons to satellite and groundbased aerosol optical depth. Journal of Geophysical Research-Atmospheres 115. https://doi.org/10.1029/2009JD012820.

Cooper, O.R., Gao, R.S., Tarasick, D., Leblanc, T., Sweeney, C., 2012. Long-term ozone trends at rural ozone monitoring sites across the United States, 1990-2010. Journal of Geophysical Research-Atmospheres 117. https://doi.org/10.1029/2012jd018261.

David, L., Nair, P., 2013. Tropospheric column O-3 and NO2 over the Indian region observed by Ozone Monitoring Instrument (OMI): seasonal changes and long-term trends. Atmos. Environ. 65, 25-39. https://doi.org/10.1016/j.atmosenv.2012.09. 033.

Duncan, B.N., Martin, R.V., Staudt, A.C., Yevich, R., Logan, J.A., 2003. Interannual and seasonal variability of biomass burning emissions constrained by satellite observations. J. Geophysic. Res. Atmos. 108 (D2). https://doi.org/10.1029/2002jd002378.

Duncan, B.N., Strahan, S.E., Yoshida, Y., Steenrod, S.D., Livesey, N., 2007. Model study of the cross-tropopause transport of biomass burning pollution. Atmos. Chem. Phys. 7 (14), 3713-3736.

EPA, 2011. Our Nation's Air - Status and Trends through 2010. EPA-454/R-12-001, ed. Research Triangle Park, NC.

Fleming, Z., Doherty, R., von Schneidemesser, E., Malley, C., Cooper, O., et al., 2018. Tropospheric Ozone Assessment Report: present-day ozone distribution and trends relevant to human health. Elementa-Science of the Anthropocene 6. https://doi.org/ 10.1525/elementa.273.

Gaudel, A., Cooper, O., Ancellet, G., Barret, B., Boynard, A., et al., 2018. Tropospheric Ozone Assessment Report: present-day distribution and trends of tropospheric ozone relevant to climate and global atmospheric chemistry model evaluation. ElementaScience of the Anthropocene 6. https://doi.org/10.1525/elementa.291.

Gelaro, R., McCarty, W., Suarez, M., Todling, R., Molod, A., et al., 2017. The Modern-Era retrospective analysis for research and Applications, version 2 (MERRA-2). J. Clim. 30 (14), 5419-5454. https://doi.org/10.1175/JCLI-D-16-0758.1.

Giglio, L., Randerson, J., van der Werf, G., 2013. Analysis of daily, monthly, and annual burned area using the fourth-generation global fire emissions database (GFED4). J. Geophysic. Res. Biogeosci. 118 (1), 317-328. https://doi.org/10.1002/jgrg.20042.

Granier, C., Bessagnet, B., Bond, T., D'Angiola, A., van der Gon, H.D., et al., 2011. Evolution of anthropogenic and biomass burning emissions of air pollutants at global and regional scales during the $1980-2010$ period. Climatic Change 109 (1-2), 163-190. https://doi.org/10.1007/s10584-011-0154-1.

Guenther, A., Baugh, B., Brasseur, G., Greenberg, J., Harley, P., Klinger, L., Serça, D., Vierling, L., 1999. Isoprene emission estimates and uncertainties for the central African EXPRESSO study domain. J. Geophys. Res. 104 (D23), 30625-30639. https:// doi.org/10.1029/1999JD900391.

Guenther, A., Geron, C., Perce, T., Lamb, B., Harley, P., Fall, R., 2000. Natural emissions of non-methane volatile organic compounds, carbon monoxide, and oxides of nirogen from North America. Atmos. Environ. 34, 2205-2230.

Jerrett, M., Burnett, R., Pope, C., Ito, K., Thurston, G., et al., 2009. Long-term ozone exposure and mortality. N. Engl. J. Med. 360 (11), 1085-1095. https://doi.org/10. 1056/NEJMoa0803894.

Jhun, I., Coull, B., Zanobetti, A., Koutrakis, P., 2015. The impact of nitrogen oxides concentration decreases on ozone trends in the USA. Air Quality Atmosphere and Health 8 (3), 283-292. https://doi.org/10.1007/s11869-014-0279-2.

Koumoutsaris, S., Bey, I., 2012. Can a global model reproduce observed trends in summertime surface ozone levels? Atmos. Chem. Phys. 12 (15), 6983-6998. https://doi. org/10.5194/acp-12-6983-2012.

Krotkov, N., Lamsal, L., Celarier, E., Swartz, W., Marchenko, S., et al., 2017. The version 3 OMI NO2 standard product. Atmospheric Measurement Techniques 10 (9), 3133-3149. https://doi.org/10.5194/amt-10-3133-2017.

Krotkov, N., McLinden, C., Li, C., Lamsal, L., Celarier, E., et al., 2016. Aura OMI observations of regional SO2 and NO2 pollution changes from 2005 to 2015. Atmos. Chem. Phys. 16 (7), 4605-4629. https://doi.org/10.5194/acp-16-4605-2016.

Lamarque, J., Bond, T., Eyring, V., Granier, C., Heil, A., et al., 2010. Historical (1850 2000) gridded anthropogenic and biomass burning emissions of reactive gases and aerosols: methodology and application. Atmos. Chem. Phys. 10 (15), 7017-7039. https://doi.org/10.5194/acp-10-7017-2010.

Lamarque, J.F., Shindell, D.T., Josse, B., Young, P.J., Cionni, I., et al., 2013. The Atmospheric Chemistry and Climate Model Intercomparison Project (ACCMIP): overview and description of models, simulations and climate diagnostics. Geosci. Model Dev. (GMD) 6 (1), 179-206. https://doi.org/10.5194/gmd-6-179-2013.

Lefohn, A., Malley, C., Simon, H., Wells, B., Xu, X., et al., 2017. Responses of human health and vegetation exposure metrics to changes in ozone concentration distributions in the European Union, United States, and China. Atmos. Environ. 152, 123-145. https://doi.org/10.1016/j.atmosenv.2016.12.025.

Levelt, P.F., Hilsenrath, E., Leppelmeier, G.W., van den Oord, G.H.J., Bhartia, P.K., et al., 2006. Science objectives of the ozone monitoring instrument. IEEE Trans. Geosci. Rem. Sens. 44 (5), 1199-1208. https://doi.org/10.1109/tgrs.2006.872336.

Lin, J., Youn, D., Liang, X., Wuebbles, D., 2008. Global model simulation of summertime US ozone diurnal cycle and its sensitivity to PBL mixing, spatial resolution, and emissions. Atmos. Environ. 42 (36), 8470-8483. https://doi.org/10.1016/j. atmosenv. 2008.08.012.

Lin, M., Horowitz, L., Payton, R., Fiore, A., Tonnesen, G., 2017. US surface ozone trends and extremes from 1980 to 2014: quantifying the roles of rising Asian emissions, domestic controls, wildfires, and climate. Atmos. Chem. Phys. 17 (4), 2943-2970. 
https://doi.org/10.5194/acp-17-2943-2017.

Liu, F., Zhang, Q., Ronald, J., Zheng, B., Tong, D., et al., 2016. Recent reduction in NOx emissions over China: synthesis of satellite observations and emission inventories. Environ. Res. Lett. 11 (11). https://doi.org/10.1088/1748-9326/11/11/114002.

Lu, X., Hong, J., Zhang, L., Cooper, O.R., Schultz, M.G., et al., 2018. Severe surface ozone pollution in China: a global perspective. Environ. Sci. Technol. Lett. 5, 487-494.

Malley, C.S., Henze, D.K., Kuylenstierna, J.C.I., Vallack, H.W., Davila, Y., et al., 2017. Updated global estimates of respiratory mortality in adults $\geq 30$ Years of age attributable to long-term ozone exposure. Environ. Health Perspect. https://doi.org/10 1289/EHP1390.

Mauzerall, D., Wang, X., 2001. Protecting agricultural crops from the effects of tropospheric ozone exposure: reconciling science and standard setting in the United States, Europe, and Asia. Annu. Rev. Energy Environ. 26, 237-268. https://doi.org/10. 1146/annurev.energy.26.1.237.

Mills, G., Pleijel, H., Malley, C.S., Sinha, B., Cooper, O.R., et al., 2018. Tropospheric Ozone Assessment Report: present-day tropospheric ozone distribution and trends relevant to vegetation. Elem. Sci. Anth. 6 (1), 47. https://doi.org/10.1525/elementa. 302.

Molod, A., Takacs, L., Suarez, M., Bacmeister, J., 2015. Development of the GEOS-5 atmospheric general circulation model: evolution from MERRA to MERRA2. Geosci. Model Dev. (GMD) 8 (5), 1339-1356. https://doi.org/10.5194/gmd-8-1339-2015.

$\mathrm{Mu}$, M., Randerson, J.T., GRvd, Werf, Giglio, L., Kasibhatla, P., et al., 2011. Daily and 3-hourly variability in global fire emissions and consequences for atmospheric model predictions of carbon monoxide. J. Geophys. Res.: Atmosphere 116 (D24). https:// doi.org/10.1029/2011JD016245.

Nielsen, J.E., Pawson, S., Molod, A., Auer, B., Silva, AMd, et al., 2017. Chemical mechanisms and their Applications in the goddard Earth observing System (GEOS) Earth System model. J. Adv. Model. Earth Syst. 9 (8), 3019-3044. https://doi.org/10. 1002/2017MS001011.

Oman, L., Douglass, A., Ziemke, J., Rodriguez, J., Waugh, D., et al., 2013. The ozone response to ENSO in Aura satellite measurements and a chemistry-climate simulation. Journal of Geophysical Research-Atmospheres 118 (2), 965-976. https://doi.org/10. 1029/2012JD018546.

Orbe, C., Oman, L., Strahan, S., Waugh, D., Pawson, S., et al., 2017. Large-scale Atmospheric transport in GEOS replay simulations. J. Adv. Model. Earth Syst. 9 (7), 2545-2560. https://doi.org/10.1002/2017MS001053.

Petetin, H., Thouret, V., Athier, G., Blot, R., Boulanger, D., Cousin, J.-M., Gaudel, A. Nédélec, P., Cooper, O., 2016. Diurnal cycle of ozone throughout the troposphere over Frankfurt as measured by MOZAIC-IAGOS commercial aircraft. Elementa: Science of the Anthropocene 4, 000129. https://doi.org/10.12952/journal.elementa. 000129.

Randerson, J., Chen, Y., van der Werf, G., Rogers, B., Morton, D., 2012. Global burned area and biomass burning emissions from small fires. Journal of Geophysical Research-Biogeosciences 117. https://doi.org/10.1029/2012JG002128.

REVIHAAP, 2013. Review of Evidence on Health Aspects of Air Pollution - REVIHAAP Project Technical Report. World Health Organization (WHO) Regional Office for Europe, Bonn. Available at: http://www.euro.who.int/_data/assets/pdf_file/0004/ 193108/REVIHAAP-Final-technical-report-final-version.pdf.

Schnell, J.L., Prather, M.J., Josse, B., Naik, V., Horowitz, L.W., et al., 2015. Use of North American and European air quality networks to evaluate global chemistry-climate modeling of surface ozone. Atmos. Chem. Phys. 15 (18), 10581-10596. https://doi. org/10.5194/acp-15-10581-2015.

Schultz, M., Schroder, S., Lyapina, O., Cooper, O., Galbally, I., et al., 2017. Tropospheric Ozone Assessment Report: database and metrics data of global surface ozone observations. Elementa-Science of the Anthropocene 5. https://doi.org/10.1525/ elementa.244.

Simon, H., Reff, A., Wells, B., Xing, J., Frank, N., 2015. Ozone trends across the United States over a period of decreasing NOx and VOC emissions. Environ. Sci. Technol. 49 (1), 186-195. https://doi.org/10.1021/es504514z.

Strahan, S.E., Duncan, B.N., Hoor, P., 2007. Observationally derived transport diagnostics for the lowermost stratosphere and their application to the GMI chemistry and transport model. Atmos. Chem. Phys. 7 (9), 2435-2445.

Strode, S.A., Rodriguez, J.M., Logan, J.A., Cooper, O.R., Witte, J.C., et al., 2015. Trends and variability in surface ozone over the United States. Journal of Geophysical Research-Atmospheres 120 (17), 9020-9042. https://doi.org/10.1002/ 2014JD022784.

Turner, M., Jerrett, M., Pope, C., Krewski, D., Gapstur, S., et al., 2016. Long-term ozone exposure and mortality in a large prospective study. Am. J. Respir. Crit. Care Med. 193 (10), 1134-1142. https://doi.org/10.1164/rccm.201508-16330C.

US EPA, 2013. Integrated Science Assessment for Ozone and Related Photochemical Oxidants. Office of Research and Development, Research Triangle Park, NC EPA/ 600/R-10/076F.

Van Dingenen, R., Dentener, F., Raes, F., Krol, M., Emberson, L., et al., 2009. The global impact of ozone on agricultural crop yields under current and future air quality legislation. Atmos. Environ. 43 (3), 604-618. https://doi.org/10.1016/j.atmosenv. 2008.10.033.

von Storch, H., Zwiers, F.W., 1999. Statistical Analysis in Climate Research. Cambridge University Press, New York, NY.

Yan, Y., Lin, J., He, C., 2018. Ozone trends over the United States at different times of day. Atmos. Chem. Phys. 18 (2), 1185-1202. https://doi.org/10.5194/acp-18-1185-2018.

Zhang, Y., Cooper, O., Gaudel, A., Thompson, A., Nedelec, P., et al., 2016. Tropospheric ozone change from 1980 to 2010 dominated by equatorward redistribution of emissions. Nat. Geosci. 9 (12), 875. https://doi.org/10.1038/NGEO2827. 